\title{
Kalevalamõõdu varasem ajalugu $*$
}

\author{
Mikko Korhonen
}

Järgnevas artiklis tahan lähemalt vaadelda mõnda probleemi, mis puudutavad soome vanas rahvaluules kasutatava värsimõõdu - kalevalamõõdu - päritolu ja kujunemist. Eelkõige püüan määratleda kalevalamõõdu ning mordva rahvaluule värsimõõtude vahekorda, balti mõju kalevalamõõdu kujunemisele ning kalevalamõõdu tekkimiseks vajalikke keelelisi tingimusi. Niisiis ei ole minu probleemid sugugi uued. Võidakse arvata, et sel teemal ei ole enam midagi öelda, et need küsimused ei paku teaduslikku huvi ning et neid on võimatu lahendada (vrd Leino 1985: 395-396). Teisalt võib väita, et senini pole kalevalamõõdu kujunemisloo uurimisel ära kasutatud kogu olemasolevat keeleajaloo materjaligi, rääkimata sellest, et oleks põhjalikumalt uuritud soome värsimõõdu ajalugu osana soome keele prosoodia arengust. Üldiselt tunnustatud seisukoha järgi sõltuvad värsimõõdud, mida antud keeles saab kasutada, ning teatava värsimõõdu sobivus teatava keelega ometi peamiselt kõne all oleva keele prosoodilisest struktuurist. Teatavasti, mida kaugemale me ajas tagasi läheme, seda enam seisame vastamisi probleemiga, et meil ei ole otseseid teadmisi läänemeresoome algkeelele eelnenud keeleperioodide prosoodia kohta. Teadlased on ometi olnud võimelised rekonstrueerima nende foneemisüsteeme ja fonotaksist kuni uurali algkeeleni välja. *1 Fonoloogiateadmiste põhjal saab teha aga ka järeldusi prosoodia kohta. Kui vaadelda soome värsimõõdu ajalugu soome keele ajaloo taustal, peaks olema võimalik saada kui mitte kindlat teadmist kalevalamõõdu päritolu kohta, siis vähemalt mõningaid lisaargumente selleteemalisele väitlusele.

\section{Mordva rahvaluule värsisüsteem}

Mordva kaheksasilbilise värsimõõdu ning kalevalamõõdu ühise algupära idee esitas Heikki Paasonen uurimuses läänemeresoome rahvaluulest, Itäsuomalaisten kansojen runoudesta aastal 1897. Paasoneni uuritud mordva laule iseloomustab lisaks värsi kaheksasilbilisusele ka tsesuur värsi keskel, parallelism ning mõningane alliteratsiooni kasutus. Need jooned meenutavad kahtlemata kalevalamõõtu. Hiljem on Paasonen veelkord mordva rahvaluule värsiehitust põhjalikult käsitlenud artiklis Über den Versbau des mordwinischen Volksliedes (1911). Suurel materjalihulgal põhinevast analüüsist ilmneb, et mordva rahvalaulu värsi silpide arv ulatub seitsmest seitsmeteistkümneni. Ühe laulu piires on värsid aga võrdse silbiarvuga. Iga värss on jagatud rütmiliselt kaheks või rohkemaks osaks - 7-silbiline värss näiteks koosneb kahest osast, millest esimene on neljasilbiline ja teine kolmesilbiline. Esineb kaht tüüpi kaheksasilbilisi värsse, ühed silbijaotusega $4+4$ ning teised jaotusega $5+3$ ning näiteks 12 -silbilisi värsse on kolm alaliiki: $4+4+4,4+5+3$ ja $5+4+3$. Värsi sisemine jaotus jääb kogu laulu kestel samaks, kõik värsid võivad kuuluda näiteks tüüpi $5+4+3$. Näib, et teatud hulk kõrvalekaldeid on lubatud nii värsside silbiarvus kui ka sisemises jaotuses, minu vaatluste põhjal rohkem moksha kui ersa lauludes, ning eriti mõlema murde itkudes ning pulmalauludes.

Niisiis on mordva lauludes kaheksasilbiline värsimõõt vaid üks paljudest, küll üsna tavaline, kuid Paasoneni andmetel ometi mitte kõige sagedasem. Tema hinnangul on kõige rohkem 10-silbiliste värssidega laule.

Selles hilisemas artiklis ei maini Paasonen enam mordva värsimõõtude ja kalevala- 
mõõdu sugulust. Ta teeb järelduse, et mordva värsisüsteem on slaavi algupära. Selline järeldus võiks näida üllatav, arvestades asjaolu, et venelastel, kellelt värsisüsteemi laenamine võiks olla kõige tõenäolisem, näib süllaabiline värsimõõt puuduvat. Paasonen on võrrelnudki mordva laule tegelikult aga valgevene rahvalauludega ning leidnud neist vaste enamikule mordva värsimõõtudest. Mõnel puhul esitab ta ka vene vaste, kuigi sealsel keelealal on need Paasoneni sõnutsi erandlikud. Kuna on ülimalt ebatõenäoline, et valgevenelased oleks kunagi elanud mordvalastele nii lähedal, et otseselt mõjutada nende värsimõõte, järeldab Paasonen, et vahendajateks on siin olnud lõunavenelased. Teisisõnu, süllaabiline värsimõõt kandunuks valgevenelastelt üle lõunavenelastele ja neilt omakorda mordvalastele. Paasoneni arvates toimus see 17. sajandil või hiljemalt 18. sajandi algul. Tema seisukohta, et mordva värsisüsteem on vene päritolu, on hiljem tunnustanud N. S. Trubetzkoy (Troubetzkoy 1921: 187), kes aga leidis, et valgevene mõju on ajaloolistel ja geograafilistel põhjustel ebatõenäoline.

Paasoneni laenuteooria tekitab mõningaid küsimusi. Kui süllaabilised värsimõõdud olid kunagi lõunavenelaste juures nii valdavad, et mõjutasid mordvalasi kasutama vastavat värsisüsteemi, kuidas oli siis võimalik, et need kadusid peaaegu jäljetult 19. sajandi lõpuks, s.o ainult 200 aastaga? Kui süllaabiline värsisüsteem ei juurdunud mordva keeltes enne 17. sajandit või isegi 18. sajandi algust, kuidas võis ta siis levida 19. sajandiks ühtlaselt mõlema peamurde alal tervikuna? Arvestades ersa- ja mokshamordvalaste keelelist erinevust kõlab see usutamatult.

Vene mõju võimaluse lükkasid tagasi Roman Jakobson ja John Lotz oma artiklis Axiomatik eines Verssystems am mordwinischen Volkslied dargelegt (1941), kus nad esitavad mordva värsisüsteemi musternäidisena loogilisest aksiomaatilisest süsteemist, mis järgib ranget struktuuri. Nende arvates ei võinud niivõrd arenenud ja korrapärane süsteem tekkida hilise välismõju tagajärjel.

Seepärast ei kõla Paasoneni laenuteooria veenvalt. Kuid kui mordva värsisüsteem ei ole vene laen, kas võiks siis olla võimalik, et nii mordva värsisüsteem kui kalevalamõõt pärinevad mingist ühisest muistsest proto-süsteemist? Kas nende värsimõõtude juured võiksid olla jälgitavad isegi kuni soome-volga algkeeleni? Muuhulgas on Paavo Ravila arvanud, et seos kalevalamõõdu ja 8-silbilise mordva värsimõõdu vahel on tõenäolisem kui kalevalamõõdu ja läti rahvalaulude värsimõõdu omavaheline seos (1935: 38).

Kalevalamõõdu ja mordva värsimõõtude ainsateks ühisjoonteks on püsiv silpide arv värsis - kalevalamõõdu korral 8, mordva värsimõõtudes 7-17 - ning asjaolu, et nad mõlemad kasutavad parallelismi ja alliteratsiooni, olgugi et mordva lauludes esineb viimast suhteliselt vähe. Kui neil olnuks ühine läänemeresoome-mordva algkuju, tuleks küsimuse alla eeldatavasti mingisugune süllaabiline värsisüsteem. Järgmiseks tuleks siis püüda vastata küsimusele, kas soome-volga, või kui täpsem olla, läänemeresoome-lapi-mordva algkeele prosoodiline süsteem oli niisugune, et süllaabilise värsisüsteemi kasutamine selles keeles olnuks tõenäoline.

\section{Värsisüsteemi sõltuvus keele prosoodilisest süsteemist}

Mitmed uurijad on märkinud, et tihtipeale kujundatakse keeles välja ja kasutatakse meelsamini selle prosoodilise ehitusega sobivaid värsisüsteeme (vt nt Sapir 1958: 230; Schmitt 1924, Sadeniemi 1949: 16-21; Lotz 1960; Leino 1982: 326-327). Seetõttu on värsimõõdud, mis põhinevad värsi silbiarvul, iseloomulikud keeltele, kus silpide rõhulisus, helilisus ja pikkus ei ole olulised - tüüpiliseks näiteks on jaapani keel. Samas kasutatakse rõhulisi värsimõõte sagedamini keeltes, kus rõhulised silbid eristuvad selgelt rõhututest ning rõhk on lingvistiliselt oluline tunnus, nagu näiteks germaani 
keeltes ja vene keeles. Vastavalt nõuab tooniline värsimõõt, et keeles oleks kasutusel toonisüsteem ning välteline värsimõõt võib eksisteerida vaid keeltes, kus silpide pikkuserinevused on olulised. ${ }^{*} 6$ Loomulikult võib teatud keelte ehitus võimaldada erinevate värsimõõtude kasutamist, sellal kui teiste keelte ehitus teeb mõnede meetrumite kasutamise üsna võimatuks. Ilmselt on keelele sobivaima värsisüsteemi leidmine omane eelkõige suulisele folkloorile. Kunstluuletajad, kes on reeglina rohkem või vähem kursis erinevate värsimõõtude ehituste ja võimalustega, võivad teadlikult eksperimenteerida mistahes hulga erinevate värsimõõtudega. Nii on tänapäeva soome keeles kasutatud kõiki siin nimetatud värsisüsteeme peale toonilise (vrd Leino 1979: 304-309; 1982: 20). Möödaminnes võib märkida, et keeleteaduse haruna on värsimõõdu tüpoloogia senini pälvinud vähest tähelepanu. Tuleks uurida laia, tüpoloogiliselt, geograafiliselt ja geneetiliselt esinduslikku valikut maailma keeltest, et määratleda, millised värsimõõdud millistes keeltes on võimalikud, millised on populaarsemad ja millised võimatud, pöörates seejuures erilist tähelepanu rahvaluulele. Seesugune uurimus annaks praegusest palju kindlama aluse aruteludele värsisüsteemi ja keele teiste süsteemide suhetest, värsimõõtude ajaloost ja keelelise suhtluse osast värsisüsteemide väljakujunemisel ning võib-olla saaks sellise uurimuse põhjal luua ka mingisuguse värsisüsteemide ja värsimõõtude implikatiivse hierarhia.

Praeguseks läbi viidud uurimustele toetudes on igal juhul ilmne, et silbirütmilised (ingl syllable timed) keeled, s.o keeled, kus kõne rütmi põhiühikuteks on silbid, soosivad süllaabiliste värsimõõtude kasutamist, kuna rõhurütmilistes (ingl stress timed) keeltes, kus keele rütmi dikteerivad rõhumaksimumid, kasutatakse meelsamini rõhulisi värsimõõte. *7

Meie probleemiks on niisiis kalevalamõõdu ja mordva värsimõõtude suhe. Kalevalamõõt on põhiolemuselt silbiline, kuid pearõhuliste silpide koht värsis sõltub ka silbipikkusest. Kalevalamõõdu võiks niisiis liigitada silbilis-rõhulis-välteliseks. See värsisüsteem sobis hästi hilise läänemeresoome algkeelega ja mõnede selle otsesteks järglasteks olnud läänemeresoome murretega, kus oli oluline pearõhulise silbi pikkus. Teisalt oli sõnarõhk neis keelevormides, nagu ka enamuses läänemeresoome keeltes tänapäeval, nii väikese lingvistilise tähtsusega, et neid ei saaks kuidagi liigitada rõhurütmilisteks keelteks. Kalevalamõõdu silbiline põhiolemus on seega ülimalt loomulik.

Mordva tänapäeva põhimurretest ehk siis mordva keeltest on ersa keel prosoodilistelt omadustelt üks tüüpilisimaid silbilise värsisüsteemi kasutamist soosivaid keeli. Sõnarõhk on grammatiliselt täiesti ebaoluline, puudub vokaalide kvantiteedikorrelatsioon ning silbid on prosoodiliselt võrdsed, vaatamata sellele, kus nad sõnas paiknevad. Ersa keel on niisiis silbirütmiline keel, nii et seal on silbilise värsimõõdu esinemine ootuspärane. Vastandina sellele määravad moksha keeles vokaalidevahelised helilisussuhted sõna pearõhu ja see võib paikneda ka mujal kui esimesel silbil. Põhimõtteliselt võib sõnarõhu määrata vokaalisuhete järgi sõnas. Teatud vokaalivastandused on rõhututes silpides neutraliseerunud ja rõhuliste silpide vokaalid võivad kõlada veidi pikemana kui rõhutute omad. Moksha keel ei ole mingil juhul nii selgelt rõhurütmiline, nagu on ersa keel silbirütmiline. Moksha keeleski on aga kodunenud silbiline värsisüsteem.

Nagu on näidanud Paavo Ravila (1929) ja Erkki Itkonen (1946), saab tänapäeva ersa ja moksha keelte vokaalisüsteeme mordva algkeele lõpustaadiumis valitsenud süsteemist lähtudes seletada kõige paremini, kui see olnuks prosoodiliselt lähedasem tänapäeva moksha keelele kui ersa keelele. Hilises mordva algkeeles oli niisiis liikuv dünaamiline rõhk, rõhutute silpide vokaalid olid redutseerunud. Need tunnused ei osuta kuidagi, et tegemist oleks puhtalt silbirütmilise keelega. Mordva silbiliste värsimõõtude päritolu 
pole niisiis probleemitu. Üksikasjalikuma uurimiseta ei saa selle kohta hetkel veel midagi öelda. Järgnevaid seletusvõimalusi tuleks võtta tööhüpoteesidena:

1. Silbiline värsisüsteem tekkis mordva algkeele arengustaadiumis, kus ka rõhutud silbid olid prosoodiliselt suhteliselt iseseisvad, s.t keel oli silbirütmiline või vähemalt mitte puhtalt rõhurütmiline. Hetkel pole kindel, kas üldse võib väita keeles sellise arengujärgu olemasolu.

2. Silbiline värsisüsteem assimileeriti mordva keelde mõnest võõrkeelest. Eeldatavasti tuleks siiski leida mingi periood enne 17.-18. sajandit, mil Paasoneni oletuse järgi mordvalased olevat laenanud värsimõõdu venelastelt.

3. Esmalt kujunesid silbilised värsimõõdud välja ersa keeles, mis silbirütmilise keelena sobis nende jaoks loomupäraselt, ning ersa keelest võeti need üle moksha keelde.

4. Silbiline värsisüsteem tekkis enne mordva algkeelt, s.o veel sellises algkeele staadiumis, millest pärinevad ka läänemeresoome keeled.

Siinkohal tahaksin kõrvale jätta kolm esimest seletusvõimalust ja keskenduda neljandale, mis väärib tähelepanu, kui tahta määratleda, kas kalevalamõõt on suguluses mordva värsimõõtudega.

\section{Läänemeresoome-eelne prosoodia}

Meie ees on niisiis küsimus, kas läänemeresoome-mordva ühise algkeele prosoodiline süsteem oli loomult sobiv silbiliste värsimõõtude jaoks. Häälikuloolistele uurimustele tuginedes võime piiritleda selle keelevormi prosoodilise süsteemi järgnevalt:

1. Pearõhk oli alati sõna esimesel silbil. Teised silbid olid rõhutud.

2. Pearõhulises silbis moodustasid lühikese ja pika vokaali foneemiopositsiooni paarid

$$
|i /-| i|,| u|-| \bar{u} /, \mid e /-/ \bar{e} / \mathrm{ja} / o /-/ \bar{o} /
$$

teistes silpides esinesid ainult lühikesed vokaalid.

3. Esimeses silbis võis eristada seitse kvalitatiivselt erinevat vokaalfoneemi; kui arvestada ka kvantiteedipaare, siis üksteist erinevat vokaalfoneemi:

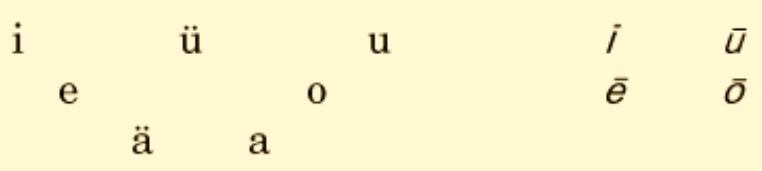

Oletatakse, et järgsilpides võis eristada vaid kolm erinevat vokaalfoneemi:

$\mathrm{e}$

ä

a või ä

i

a

Nendest kolmest oli opositsiooni / $\ddot{a} /-/ a /$ funktsionaalne koormus vokaalharmoonia tõttu iseäranis väike. Teises silbis olid need vokaalid omavahel opositsioonis ainult juhul, kui esimese silbi vokaaliks oli $/ i /$. Kolmandas ja järgnevates silpides oli / $\ddot{a} /-/ a /$ opositsioon juba alati neutraliseeritud. Järgsilpide kolmeliikmelise vokaalisüsteemi hüpoteesil on kaks nõrka kohta: 
tagurpidine vokaalikolmnurk ja lahtiste vokaalide paari äärmiselt madal funktsionaalne koormus. Niisiis oleks õigustatud arvamus, et järgsilpides võis olla olnud vaid kahe vokaali vastandus:

i

a (foneetiliselt $ə-\dot{a})$

Sellisele kahe või kolme foneemi süsteemile on iseloomulik, et iga foneemi hääldusala on väga suur ning et foneemid realiseeritakse rohkem või vähem redutseerunult.

4. Konsonandiga lõppesid pigem rõhulised kui rõhutud silbid. Niisiis võis leida konsonantide kombinatsioone sagedamini ja suuremas mitmekesisuses esimese ja teise silbi piiril kui teistes silbipositsioonides.

Märgid osutavad selgelt, et tegemist on rõhurütmilise keelega. Läänemeresoome-lapimordva algkeele ja tema eellaste prosoodiat näib olevat iseloomustanud terav kontrast rõhuliste ja rõhutute silpide vahel. Ei saa järeldada, et kaasrõhk oleks selles süsteemis olnud lingvistiliselt kuidagi oluline. Rõhuliste silpide arvukate vokaalivastanduste, pikkussuhete ja esimesele silbile järgnevate konsonandikombinatsioonide väljaütlemine pidi nõudma hoolikat artikulatsiooni ja suurt hääldusenergiat, kuna teised silbid nõudsid artikulatsiooni ja energiat minimaalselt. Olgugi, et meil ei ole otseseid teadmisi nende varajaste keelestaadiumide prosoodiast, osutab kõik sellele, et läänemeresoome-lapi algkeelele eelnevad keelevormid kuni uurali algkeeleni välja pidid olema väga sobivad esimesele silbile koonduvale sõnarõhule. Esimese silbi domineeriv staatus sõnarõhu suhtes ilmneb selgelt uurali keelte vokaaliajaloost: järgsilpide vokaalid on enamikus keeltes kas kadunud või redutseerunud. Kõige paremini on nad säilinud läänemeresoome ja lapi keeltes, kuid ka siin on järgsilpide vokaalisüsteemis toimunud põhjalikud muutused.

Läänemeresoome ja mordva ühise algkeele prosoodiline struktuur oli niisiis selline, et selles ei saanud kergesti koduneda silpide prosoodilisel võrdsusel põhinev silbiline värsimõõt. Kui selles keeles või mõnes tema eellastest kuni uurali algkeeleni eksisteeris mingisugune meetriline luule, siis on selles kõige tõenäolisemalt kasutatud rõhulist värsisüsteemi: värsijala tõususilbile, mis oli alati pearõhuline, järgnes üks või rohkem rõhutut langusilpi, nagu ka näiteks suur-vene bõliinas. *2 Kui läänemeresoome ja mordva ühine algkeel ei olnud sobiv silbilise värsimõõdu jaoks, siis ei ole mõtet nimetatud algkeelest püüda leida ei kalevalamõõdu ega ka praeguste mordva värsimõõtude eellast, vähemalt mitte otsest eellast, vaid tuleb arvata, et need on kujunenud teineteisest sõltumatult. Milline ka oleks mordva värsisüsteemi päritolu, on ebatõenäoline, et see oleks tekkinud enne mordva algkeelt. Eriti moksha keeles on toimunud palju hiliseid sise- ja lõpukadusid, millega seoses on vähenenud silpide arv sõnades. Vaatamata sellele järgivad lauluvärsid väga korrektselt värsimõõdu poolt määratud silbiarvu. Kas võiks see tõendada, et vastav värsisüsteem on hiline?

Ka kalevalamõõdu jaoks sobivad keelelised tingimused tekkisid tõenäoliselt alles läänemeresoome algkeeles seoses vokaalisüsteemi uuenemisega järgsilpides, milles lisandunud vokaalivastandused vähendasid prosoodilist kontrasti rõhulise ja rõhutute silpide vahel. Esimeseks sündmuseks selles arenguahelas oli tõenäoliselt illabiaalse vokaali ja $v$ kombinatsioonist labiaalvokaali väljaarenemine järgsilpides varases läänemeresoome algkeeles (Itkonen 1954); edasises arengus lisandus /a/-/ä/ vastanduse funktsionaalse koormuse suurenemine, kuna /a/ muutus võimalikuks 
esimese silbi /e/ järel (sõnades nagu mela, kela) ja üha sagedamini ka / $i /$ järel; seejärel tekkisid järgsilpides vokaalivastandused $/ i /-/ e /, / o /-/ u /$ ja $/ u /-/ \ddot{u} /$. Hilise läänemeresoome algkeele lõpul kasutati järgsilpides samu lühikesi vokaalfoneeme, mida esisilbiski, ainukeseks võimalikuks erandiks oli /ö/. Tekkisid ka / $i /$-ga lõppevad diftongid. Järgsilpide hääldamine nõudis nüüd rohkem energiat ja hoolikamat artikuleerimist. Prosoodiline kontrast pearõhulise silbi ja teiste silpide vahel oli vähenenud. Selle arenguahela algusaega võime paigutada kaasrõhu muutumise lingvistiliselt oluliseks teguriks - see on iseloomulik läänemeresoome ja lapi keeltele. Selle tulemusena jagunes kõne ühe-, kahe- ja kolmesilbilisteks jalgadeks. Nelja- või enama silbilised sõnad koosnesid kahest või enamast jalast. Selle arengu jäljed on läänemeresoomes ja lapis väga sarnased. Järgsilpide prosoodilisele tähtsusele osutab ka astmevahelduse teke, vähemalt foneetilise tendentsina, juba varases läänemeresoome algkeeles.

\section{Balti laen?}

Niisiis võib eeldada, et prosoodilised tingimused põhiolemuselt silbilise kalevalamõõdu kujunemiseks ei tekkinud enne ülalpiiritletud keelemuutusi varases ja kesk-läänemeresoome algkeeles. Kas läänemeresoomlased võtsid nüüd kuidagi ka malli balti rahvaluulest? Alates sellest, kui A. R. Niemi 1918. aastal oma põhjalikus uurimuses osutas, et läti rahvalaulude värsimõõt ja kalevalamõõt on sarnased, jõudes nõnda järeldusele, et läänemeresoomlased on oma vanade rahvalaulude värsimõõdu omandanud balti rahvastelt, peetakse kalevalamõõdu algupära küsimust üldiselt lahendatuks. Arvamused on lahknenud peamiselt vaid ses suhtes, kui ulatuslik oli balti mõju osa kalevalamõõdu kujunemisel. On esitatud ka üksikuid vastupidiseid vaateid. Nendest olen juba maininud Ravila arvamust (1935), mille järgi kalevalamõõt on pigem seotud mordvalaste kui baltlaste värsimõõtudega. Pentti Leino, kes mingil ajal (1982: 323) tundus toetavat balti teooriat, on hiljem (1985: 396) omandanud skeptilise suhtumise selle suhtes, et üldse on võimalik tõestada kalevalamõõdu üht või teist päritolu. Vaatamata sellele on väide kalevalamõõdu balti päritolust minu meelest ometi hindamist väärt ka nende keeleajaloo teadmiste põhjal, mis meil on läänemeresoomlaste ja baltlaste kontaktide kohta.

Kui kalevalamõõdu mall saadi baltlastelt, oleks kõige loomulikum, et ajaliselt langeb see kokku tugevate balti mõjudega läänemeresoome algkeelele. Selle tagajärjeks pole üksnes arvukad vanad balti laensõnad läänemeresoome keeltes, vaid ka teatud struktuurilised muutused läänemeresoome algkeeles, nagu näiteks mitmesugused häälikumuutused (Posti 1953), partitiiv- ja akusatiivobjekti kasutuse muutumine (Kont 1963; Larsson 1981) ning adjektiivatribuudi ühildumine (Kalima 1936: 197). Laensõnade leviku ja nendes toimunud häälikumuutuste põhjal võime järeldada, et balti kontaktid algasid tõenäoliselt enne varase läänemeresoome algkeele perioodi lõppu ja lõppesid enne hilise läänemeresoome algkeele perioodi lõppu. Seda, et lähtekeeleks oli balti algkeel või mõni temaga tihedalt seotud keel, näitab laensõnade häälikuline ehitus. Praegustest balti keeltest sarnaneb leedu keel oletatava algkujuga enam kui läti keel, kus iseseisva ajaloo jooksul toimunud muutusi on rohkem kui leedu keeles. Teisalt eksisteerib vaid läti keeles värsimõõt, mida on peetud kalevalamõõdu eeskujuks. Selle värss koosneb neljast kahesilbilisest värsijalast ja see jaguneb kaheks tsesuuriga eraldatud dipoodiks. Dipoodi teine värsijalg võib koosneda ka ühest pikast silbist, stroof koosneb tavaliselt neljast värsist. $\stackrel{* 3}{3}$ Näiteks 
Man ka/sina // veenu / ragu. (Tavaline trohheus: $2+2$ // 2+2)

Masa/jam // kamba/ri. $(2+1 / / 2+1)$

(Niemi 1918: 14)

Leedu laulud erinevad läti lauludest oluliselt. Neil on palju erinevaid värsimõõte, millest ükski pole otseselt võrreldav eespool kirjeldatud läti daina värsimõõduga (vt Niemi 1913; Senkus 1957). Kazimieras Senkus väidab, et leedu luule vanimat kihti esindab laulutüüp, milles nii värsimõõt kui ka silpide arv värsis on väga vabad ning mis ei järgi kindlat stroofistruktuuri (samas: 164).

Kui tahetaks balti keeltes leida värsimõõtu, mis kõige paremini esindaks midagi, mida võiks kutsuda proto-balti värsimõõduks, oleks loomulik otsida seda leedu keelest, mis on säilitanud balti algkeele rõhusüsteemi ning on muuski suhtes väga arhailine. Läti keeles seevastu on rõhk kinnistunud sõna esisilbile, võimalik, et läänemeresoome keelte mõjul. Ei kõla usutavalt, et läti keel säilitanuks proto-balti meetrika vaatamata keeles toimunud suurtele muutustele ja samal ajal oleks muus osas arhailisemas leedu keeles algne värsisüsteem kadunud. Vastupidi, oleks loomulikum kujutleda, et seni, kuni läti keeles polnud pearõhk kinnistunud esisilbile, ei saanud trohheiline värsimõõt seal kasutusele tulla. Kui see kujutelm on õige, siis tuleks läti daina värsimõõtu käsitada uuendusena, mis leidis aset läti keele iseseisva arengu kestel. Kas oleks sel juhul võimalik, et seesugune suhteliselt hiline ja piiratud uuendus võis kanduda läänemeresoome rahvaluulesse ning levida üle kogu Eesti, Soome ja Karjala? Ükski teine spetsiifiline läti joon pole saavutanud nii laia levikut. Läti keelel oli tugev mõju liivi keelele ja teatud arvu suhteliselt hiliseid läti laene võib leida eesti keeles, mitte aga teistes läänemeresoome keeltes (vt Kalima 1936: 49; Suhonen 1973). Näib uskumatu, et läti meetriline süsteem oleks ületanud need piirid, mida ükski teine keele struktuuriseaduspära ega element pole ületanud.

Niisiis on kalevalamõõdu balti algupära teooria nii mõju ajastamise kui ka leviku osas problemaatiline. Kui me just tahame näha mingisugust mõju, siis võiks pigem oletada, et läti daina meetrum on läänemeresoome algupäraga. Liiatigi avaldub läänemeresoome mõju läti keeles mitmel moel, nagu näiteks laensõnades, aga võimalik, et ka prosoodias, mille väljenduseks oleks nimelt rõhu kinnistumine sõna esisilbile.

Sõnu virsi ja kannel, mis arvatakse olevat balti päritolu, on samuti tõlgendatud kaudse tõendina kalevalamõõdu balti algupärast. Kui juba nii tähtsad kalevalamõõdulise rahvaluule põhimõisted on laenatud, miks siis mitte laulude värsimõõt? Nimetatud sõnade kaalukust tõendusmaterjalina vähendab ometi fakt, et nende balti algupära ei ole väljaspool kahtlust. Soome etümoloogilises sõnaraamatus on mõlemad sõnad varustatud küsimärgiga. Eino Niemineni järgi on sõna virsi ühendamine tema balti vastega puhas spekulatsioon (1945: 527; 1957: 195 märkus 3). Etümoloogia teeb problemaatiliseks fakt, et balti sõna - leedu var̃das 'nimi', läti vàrds 'sõna, kõne, lubadus, nimi'; vana-preisi $\boldsymbol{w} \tilde{r} \boldsymbol{r} d s$ 'sõna' - teises silbis on algselt olnud $a$, läänemeresoome virsi aga on $e$-tüveline. Veelgi enam, vaid vana-preisi keeles on sõna esimeses silbis $i$, leedu ja läti keeles aga $a$, mis ei saa olla läänemeresoome $i$ vasteks. Teisalt on Jorma Koivulehto täheldanud, et läänemeresoome $r$-tüvekonsonantidega sõnad on tavaliselt kas laensõnad või vanad konsonanttüvelised tuletised (1979). See tähelepanek toetab omakorda oletust, et sõna virsi on laenulise päritoluga. Sõnale ei ole pakutud ühtki muud etümoloogiat. Läänemeresoome sõna kannel, kantele pole peetud mitte ainult balti laensõnaks, vaid ka omasõnaks, sel juhul oleksid leedu kañkles, läti kuõkle 
'kannel' läänemeresoome laenud. Minu meelest ei takista meid miski oletamast, et nii kannel kui ka teine iidne sõna muusikainstrumendi jaoks - kannus, lapi govdes, Kildini lapi kümdes 'shamaanitrumm' võiksid olla varase algläänemeresoome sõna *komta 'kaas' või selle edasiarenduste tuletised ja seega omasõnad. Sõnad virsi ja kannel ei ole niisiis probleemitud balti laenud sel määral, et neist võiks lähtuda järelduste tegemisel kalevalamõõdu algupära kohta. Isegi kui nende balti algupära oleks kindel, oleks nende tõenduskaalukus kalevalamõõdu suhtes tühine, arvestades asjaolu, et kalevalamõõdu jaoks ei näi balti poolel olevat ühtki ajaliselt ega ka ruumiliselt sobivat allikat.

\section{Läänemeresoome algkeele häälikuline areng kalevalamõõdu tekkimise eeldusena}

Kalevalamõõdu teke ei nõua minu meelest mingeid võõrmõjul põhinevaid seletusi. Läänemeresoome algkeele häälikumuutused ja nendega kaasnevad prosoodilised muutused lõid küllaldased tingimused uue värsisüsteemi spontaantekke jaoks. Näib olevat võimatu kindlaks määrata, kas uus värsisüsteem tekkis mingi vana, võimalik, et rõhulise värsisüsteemi kõrvale ja tõrjus selle välja, kuna sobis paremini keele prosoodiaga, või muutus oletatav vana süsteem uueks järk-järgult. Üldine arvamus näib olevat, et kalevalamõõdu varaseimat vormi esindavad puhttrohheilised värsid nagu

Itse / laulan / milloin / kuulen.

Vaka / vanha / Väinä / möinen.

Murtud värsid nii nagu ka pearõhulise silbi pikkusreeglid arvatakse olevat välja kujunenud hiljem (vrd Kuusi 1978; Leino 1974, 1985). Selline järjekord on loogiline, kui lähtuda eeldusest, et kalevalavärsi malliks on olnud balti trohheiline värss. Kui me aga hülgame kalevalamõõdu balti päritolu teooria või vähemasti kahtleme selles sügavalt, on meil vabadus interpreteerida kalevalamõõdu erinevate variantide - kalevalakeele murrete, ütleks Matti Kuusi - ajaloolisi suhteid uuel viisil, samas avaneksid uued lähenemisvõimalused kalevalamõõdu enese arengu käsitlemisel. Tahaksin siinkohal tuua vaid ühe alternatiivse stsenaariumi, kuidas kalevalamõõt võis kujuneda, kui ta oli mingi varasema meetrilise traditsiooni orgaaniliseks edasiarenduseks.

Nagu olen öelnud juba eespool - kui läänemeresoome algkeeles või mõnes talle eelnenud faasis eksisteeris mingi korrapärane värsimõõt enne kalevalamõõtu, siis oli see tõenäoliselt laskuv rõhuline värsimõõt, kus (pea)rõhuline silp asetses värsijala tõusus ning üks või enam silpi värsijala langus; lisaks rõhule võisid silbi prominentsusfaktoriteks olla selle pikkus ja isegi helilisus. Rütmilise korrapära nõude tõttu laulu esitamisel on üksikud värsijala langu silbid seda lühemad, mida rohkem neid sinna tuleb mahutada. See "isokrooniline printsiip" on iseloomulik just rõhurütmilistele keeltele ja vastavalt rõhulistele värsimõõtudele. *4 Kui värsijala langu silbid on enamasti lühikesed ega sisalda foneemivastandusi, mis nõuaksid hoolikat artikulatsiooni, on isokronismi nõuet rahuldada lihtne. Nii oli see ka varasele läänemeresoome algkeelele eelnenud keelevormis. Kuid kui läänemeresoome algkeeles muutusid pearõhuta silbid eelkõige vokaaliparadigma laienemise tõttu iseseisvamaks, siis ei olnud kõigi nende mahutamine värsijala langu enam nii lihtne kui varem. Nüüd võidi hakata rütmistama laulu nii, et võimalusel jäeti värsijala langu vaid üks silp. Kaasrõhu teke ja tugevnemine nelja- ja rohkemasilbiliste sõnade paarituarvulistel silpidel (v.a viimane silp) aitas kaasa uue värsimõõdu kinnistumisele. See tegi võimalikuks värsid, mis koosnesid kahesilbilistest jalgadest nagu 
Ruven/nenko / laula/mahan.

Sari/olan / juomin/keihin.

Ühe- ja kolmesilbiliste jalgade sobitamine uue prosoodia nõuetele vastavatesse värsitüüpidesse ei olnud niisama lihtne. Põhimõtteliselt oleks mõeldavad kolm alternatiivi:

1. Asendada vajadusel trohheus daktüliga. Teatud tingimustel nii on juhtunudki. "Klassikalises" kalevalamõõdus võib esimene värsijalg sisaldada kolm, mõnikord isegi neli silpi. Näiteks

Tuop oli / Ahti / Saare/lainen.

Sentä ei / soita / kante/leni.

Eesti lauludes on see võimalik ka teistes värsijalgades (Anderson 1935; Kuusi 1978: 212). Näiteks

Mis tuli / karates / kalda/asse.

Lehm oli / laudas, / laps oli / süles.

Vääriks uurimist, kas seesuguseid värsse tuleks pidada reliktideks ajast, kui oli käimas läänemeresoome-eelsest rõhulisest värsimõõdust kalevalamõõdu väljakujunemise protsess. Võiks oletada, et selline vahepealne staadium oli loomulikuks jätkuks täiesti dünaamilisele värsimõõdule ning moodustas sobiva lähtekoha silbilisele kaheksasilbilisele värsimõõdule, kohandades ka kolmesilbilised jalad runolaulu trohheilise rütmiga. Nii jõuame teise alternatiivi juurde.

2. Asetada ühe- ja kolmesilbilised jalad kaheksasilbilisse värssi hoolimata sellest, et sõnarõhk ei järgiks enam trohheilist rütmi. Näiteks

Miele/ni mi/nun te/kevi.

Suot su/lavat / maat va/luvat.

3. Asendada neljasilbiline dipood vajadusel kolmesilbilisega, nii nagu toimiti läti daina puhul. Sel juhul oleksid võimalikud järgmised värsikonstruktsioonid

Toisin / ennen, // toisin / eilen. (Tavaline trohheus: $4+4$ silpi)

Sula/vat // sanat / suussa. (3+4 silpi)

Sanat / suussa // sula/vat. ( $4+3$ silpi)

Sanat/kin // sula/vat. (3+3 silpi) 
Kalevalamõõt seda võimalust minu teada ei ole kasutanud, mis jällegi räägib selle balti algupära vastu. Kui malliks oleks olnud värsimõõt, mida kohtame läti dainades, eeldaksin, et sellest oleks jäänud jälgi ka läänemeresoomlaste vanadesse lauludesse.

Läänemeresoome algkeele häälikulist arengut arvesse võttes on loomulik, et käibele läks teine alternatiiv. Järgsilpide vokalismi muutuste tõttu tasandus prosoodiline erinevus rõhuliste ja rõhutute silpide vahel ning sõna erinevad silbipositsioonid võrdsustusid prosoodiliselt üha enam. Keel muutus rõhurütmilisest keelest silbirütmiliseks või pigem jalarütmiliseks keeleks. $\stackrel{* 5}{5}$ Seoses sellega hakkas läänemeresoome algkeel eelistama silbilisi värsimõõte. Kui silpide arv värsis kinnistus kaheksale, jäi üle vaid sobitada ka ühe- ja kolmesilbilised jalad standardpikkusega värssidesse.

Olen siin käsitlenud vaid mõningaid kalevalamõõdu varasemat ajalugu puudutavaid küsimusi. Oma uurimuses olen jõudnud järeldusele, et soome rahva vanade runode värsimõõt ei saa olla sama algupära kui mordva süllaabilised värsimõõdud, et see ei ole ka balti päritoluga või balti mõjude tagajärg, vaid tekkis iseseisvalt läänemeresoome algkeele häälikuliste ja prosoodiliste muutuste tagajärjel.

\section{Kirjandus}

Anderson, Walter 1935. Studien zur Wortsilbenstatistik der älteren estnischen Volkslieder. ACUT (Acta et Commentationes Universitatis Tartuensis). B XXXIV:1. Tartu. Itkonen, Erkki 1946. Zur Frage nach der Entwicklung des Vokalismus der ersten Silbe in den finnish-ugrischen Sprachen, insbesondere im Mordwinischen. FUF (Finnisch-ugrische Forschungen) 29, 222-337.

Itkonen, Erkki 1954. Über die suffixalen Labialvokale im Lappischen und Ostseefinnischen. Scandinavica et Fenno-ugrica. Studier tillägnade Björn Collinder den 22 juli 1954, 183-191. Uppsala.

Jakobson, Roman - Lotz, John. Axiomatik eines Verssystems am mordwinischen Volkslied dargelegt. Thesen zu einem Vortrag im Ungarischen Institut, Stockholm, am 8:ten April 1941. Stockholm.

Kalima, Jalo 1936. Itämerensuomalaisten kielten balttilaiset lainasanat. Helsinki.

Koivulehto, Jorma 1979. Baltisches und Germanisches im Finnischen: die finn. Stämme auf -rte und die finn. Sequenz VrtV. Explanationes et tractationes fenno-ugricae in honorem Hans Fromm. Münchener Universitäts-Schriften. München.

Kont, Karl 1963. Käändsõnaline objekt läänemeresoome keeltes. Tallinn.

Korhonen, Mikko 1974. Oliko suomalais-ugrilainen kantakieli agglutinoiva? Eli mitä kielihistoriallisista rekonstruktioista voidaan lukea ja mitä ei. Virittäjä, 243-257.

Kuusi, Matti 1978. Kalevalakielen kysymyksiä. Virittäjä, 209-224.

Larsson, Lars-Gunnar 1981. Studier i de östersjöfinska språkens partitivbruk. Uppsala.

Lehiste, Ilse 1977. Isochrony reconsidered. Journal of phonetics 5, 253-263.

Lehiste, Ilse 1983. The role of prosody in the internal structuring of a sentence. Proceedings of the XIIIth international congress of linguists, August 29. September 4, 1982. Tokyo, 220-231.

Lehiste, Ilse 1984. The metric structure of a recited Finnish spell. UAJb (Uralische-Altaische Jahrbücher). Neue Folge, 4: 83-89.

Leino, Pentti 1974. Kalevalamitan ongelma. P. Virtaranta et al. (eds.) Sampo ei sanoja puutu: 
Matti Kuusen juhlakirja. Kalevalaseuran vuosikirja 54. Helsinki, 243-269.

Leino, Pentti 1979. Suomen kielen metriset systeemit ja mittatyypit. Virittäjä, 302-340.

Leino, Pentti 1982. Kieli, runo ja mitta. Suomen kielen metriikka. Helsinki.

Leino, Pentti 1985. Metriikan anti kielentutkimukselle. Virittäjä, 390-407.

Lotz, John 1960. Metric typology. T. A. Sebeok (ed.) Style in language. Cambridge, Mass.

Niemi, A. R. 1913. Tutkimuksia liettualaisten kansanlaulujen alalta. AASF (Suomalaisen

Tiedeakatemian Toimituksia) B: XII.

Niemi, A. R.1918. Vanhan suomalaisen runomitan synnystä. Suomi IV: 19. Helsinki.

Nieminen, Eino 1945. Orsi, aarto ja hirsi. Virittäjä, 524-533

Nieminen, Eino 1957. Itämerensuomalaisten kielten vanhimmista balttilaisperäisistä lainasanoista kuvastuvia lähdekielen ominaisuuksia. STAEP (Suomalaisen Tieteakatemian esitelmät ja pöytäkirjat) 1956, 190-209. Helsinki.

Paasonen, Heikki 1897. Itäsoumalaisten kansojen runoudesta. Valvoja 17, 1-26.

Paasonen, Heikki 1911. Über den Versbau des mordwinischen Volksliedes. FUF (Finnisch Ugrische Forschungen) 10, 153-191.

Posti, Lauri 1953. From Pre-Finnic to Late Proto-Finnic. FUF (Finnisch-ugrische

Forschungen) 31, 1-91.

Ravila, Paavo 1929. Über eine doppelte Vertretung des urfinnisch-wolgaischen *a der nichtersten Silbe im Mordwinischen. FUF (Finnisch-ugrische Forschungen) 20: 83-120.

Ravila, Paavo 1935. Vanhan suomalaisen runomitan probleema. Virittäjä: 35-44.

Sadeniemi, Matti 1949. Metriikkamme perusteet. Helsinki.

Sapir, Edward 1958 (1921). Language. An introduction to the study of speech. New York. Schmitt, Alfred 1924. Untersuchungen zur allgemeinen Akzentlehre. Heidelberg.

Senkus, Kazimieras 1957. Die Formen der litauischen Volkslieder. Commentationes Balticae III, 4: Bonn. 119-65

Suhonen, Seppo 1973. Die jungen lettischen Lehnwörter im Livischen. SUST (Suomalaisugrilaisen Seuran Toimituksia) 154. Helsinki.

Troubetzkoy, N. 1921. De la valeur primitive des intonations du slave commun. Revue des études slaves I: 171-187.

Tõlkinud Mari Sarv

\section{MÄRKUSED}

* Tõlgitud Korhonen, M. 1994. The Early History of the Kalevala Metre. Songs Beyond the Kalevala. Transformations of Oral Poetry. Edited by Anna-Leena Siikala \& Sinikka Vakimo. (Studia Fennica Folkloristica 2) Helsinki 1994. pp. 75-87.

See artikkel põhineb varasemal soomekeelsel versioonil Kalevalamitan varhaishistoriaa, Suomalais-Ugrilaisen Seuran Aikakauskirja 81, 1987. Helsinki. lk. 175-191.

1. Ma ei puuduta siin nende rekonstruktsioonide usaldatavust, seda olen käsitlenud mujal (Korhonen 1974).

2. Ei saa täielikult välistada võimalust, et lisaks rõhule on silpide meetrilist prominentsust mõjutanud silbipikkus. Silbid, mis algkeeles oletatavasti on olnud rõhulised, võib jaotada mitmeks tüübiks vastavalt vokaalikvantiteedile, sonoorsusele ja sellele kas nad on lahtised või kinnised. Rõhutud silbid on omakorda jagunenud erinevateks kategooriateks vastavalt 
nende vokaalide sonoorsusele ja sellele, kas nad on lahtised või kinnised. Sõnavormid nagu *munan ja *min'än (soome miniän), kus esimene silp oli võimalikest variantidest kõige nõrgemat tüüpi (lühike silp lühikese vokaaliga, mis on võimalikult ebasonoorne) ja teine silp võimalikest variantidest tugevaimat tüüpi (pikk silp kõige sonoorsema vokaaliga) võisid vägagi erineda oma meetrilise ja prosoodilise staatuse poolest sellistest sõnavormidest nagu näiteks *s ōne (soome suoni) ja *täshte (soome tähti), kus esimene silp ei saanud olla enam tugevam ja teine silp enam nõrgem.

3. Läti rahvalaulude värsimõõt erineb niisiis märkimisväärselt kalevalamõõdust. See ongi põhipõhjuseks, miks Ravila pidas balti mõju võimalikkust küsitavaks (1935: 38).

4. Isokronismi kohta on kirjutatud palju. Vähesed eitavad fenomeni enese olemasolu isegi kui selle foneetiline loomus on vastuoluline. Üksikasju vt nt Lehiste 1977 (hea ülevaade viimastest uurimustest), 1983, 1984; Leino 1982, 278-279.

5. Terminit 'jalarütmiline' (ingl. foot-timed) on kasutanud läänemeresoome keelte prosoodilist struktuuri kirjeldades Kalevi Wiik (uurimustes, mis käsitlevad soome keele prosoodiat). Lapi keelt võib ses suhtes samuti pidada jalarütmiliseks.

6. Värsisüsteemide ja -mõõtude eesti- (ja ehk ka muu-) keelsete nimetuste puhul tekitab segadust asjaolu, et keeltes, milles toonikontuur ei ole sõnu eristav, ei ole toonimuutused ka värsimõõdus olulised ja selliskeelsetes värsisüsteemiliigitustes võidakse kergelt mööda minna toonidistinktsioonil põhinevaist värsisüsteemidest. Rõhulise/aktsendilise värsisüsteemi paralleelnimetusena on kasutatud ka terminit tooniline värsisüsteem ja näiteks silbilisrõhulise sünonüümina süllabotooniline. Olgugi, et mõlemaid asjaolusid arvestades võib termin tooniline segadust tekitada, on see siiski sobivaim nimetus toonisüsteemi kasutavate värsimõõtude jaoks. Olen otsustanud seda siinkohal kasutada ja suuremat segadust vältida käesoleva alamärkuse abil. - Tlk.

7. timed-komponendi vastena ühendites syllable, stress, ja foot timed olen lühiduse huvides kasutanud tähenduselt sobivat, kuid mitte päris sõnasõnalist -rütmiline. Võrdluseks, M. Lotman on oma artiklis «Värsisüsteemidest» - Akadeemia 1998, nr 9, lk 1859 sama mõiste tähistamiseks kasutanud kombinatsiooni loendava rütmiga, nt silpe loendava rütmiga keeled. Tuleb veel märkida, et taas võib tekkida terminoloogine segadus - Korhoneni ingliskeelse artikli terminile stress timed languages vastab Lotmani artiklis ühend takte loendava rütmiga keeled. Korhoneni ingliskeelse artikli aluseks olevas soomekeelses variandis märgib tahtiajatteinen hoopis inglise keele foot timed ehk käesoleva tõlke terminoloogiat kasutades jalarütmilisi keeli. - Tlk. 